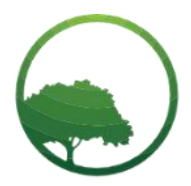

Research in Business \& Social Science

IJRBS VOL 10 NO 6 ISSN: 2147-4478

\title{
Motivation and loyalty of Indonesian medical tourists toward Malaysian health services
}

\author{
(iD) Morissan ${ }^{(a) *(1 D)}$ Gerald Goh Guan Gan ${ }^{(b)}$ \\ (a) Faculty of Communication, Universitas Mercu Buana, Indonesia \\ (b) Faculty of Business, Multimedia University, Malaysia
}

\author{
A R T I CLE IN F O \\ Article history: \\ Received 12 August 2021 \\ Received in rev. form 18 Sep. 2021 \\ Accepted 21 Sept 2021 \\ Keywords: \\ Loyalty, medical tourists, hospitals, \\ Indonesia, Malaysia \\ JEL Classification: \\ I10; I14; I20; I30
}

\begin{abstract}
A B S T R A C T
This study aims to find out which factors, between the word of mouth (WoM) or marketing promotion programs (MPP), that drive motivation (push and pull); to explore the influence of travel motivation toward satisfaction, and to investigate the satisfaction effect of medical tourists with loyalty. This study used a survey method by distributing questionnaires to medical tourists from Indonesia $(N=152)$ who have visited hospitals in Malaysia for medical care at least once. Data analysis was carried out using several statistical procedures that include a multivariate test, multiple linear regression and a simple linear regression. The findings show that there is a statistically significant difference in the push and pull motives based on the influencers (WoM or MPP). The effect size of both push and pull is almost equal. The relationship between push or pull and satisfaction is also statistically significant as $41.3 \%$ of the variance in the satisfaction is explained by the push and $51.8 \%$ by pull factors. Finally, satisfaction is a significant predictor for loyalty while $90.2 \%$ of the variance in loyalty is explained by satisfaction.
\end{abstract}

(C) 2021 by the authors. Licensee SSBFNET, Istanbul, Turkey. This article is an open access article distributed under the terms and conditions of the Creative Commons Attribution (CC BY) license (http://creativecommons.org/licenses/by/4.0/).

\section{Introduction}

In 2018, before the coronavirus disease 2019 (COVID-19) pandemic struck the world, more than 670,000 Indonesians have undertaken medical care, both outpatient and inpatient, in various private hospitals in Malaysia. This means that $60 \%$ of foreign patients seeking treatment in Malaysia come from Indonesia. In the global economy, medical tourists, or people who travel abroad to get health services, have attracted attention.

Medical tourism has become a growing industry where patients deliberately travel abroad to get non-emergency medical services. This niche area in the tourism industry has become so profitable and identified as one of the contributors to economic growth (Klijs et al, 2016). In 2018, Malaysia's income from medical tourism is around 1.5 billion Malaysian ringgit (USD 358.74 million), an increase of almost one billion ringgit (67\%) since 2011 (Nathan, 2018; Thomas, 2019). In 2019, Malaysia projects hospital revenue of RM1.8 billion from health travellers which generate an economic impact of RM6 billion. There are around 250 private hospitals in Malaysia, although less than 50 of them are interested in seeking medical tourists (Jais, 2017). The main market for medical tourism in Malaysia is dominated by Indonesia which generates $62 \%$ of total revenue and total health services. Patients from Indonesia dominate hospitals in Malaysia to obtain various health services in the neighbouring country. In 2018, more than 670,000 Indonesians had received medical treatment, both outpatient and inpatient, in various private hospitals in Malaysia (Handayani, 2019). This means that $60 \%$ of foreign patients seeking treatment in Malaysia come from Indonesia while the rest comes from other countries such as Vietnam, China, Australia, Myanmar (Handayani, 2019). Every year patients from Indonesia who seek treatment in Malaysia grow 12-18\%. With a population of more than 260 million people, Indonesia is the largest market for Malaysia (Briandana et al, 2018).

* Corresponding author. ORCID ID: 0000-0002-8176-7515

(C) 2021 by the authors. Hosting by SSBFNET. Peer review under responsibility of Center for Strategic Studies in Business and Finance. https://doi.org/10.20525/ijrbs.v10i6.1325 
The use of the terms 'health tourism' or 'medical tourism' has become a contentious topic recently. In the literature review, it was found many definitions of health tourism. For example, the definition by The International Union for Official Tourism Organizations (IUOTO, 1973) suggested an initial definition of health tourism as "the provision of health facilities that utilize the country's natural resources, in particular, mineral water and climate" (p. 7). This concept is further expanded by linking health tourism with tourism facilities (Goodrich \& Goodrich, 1987; Vajirakachorn, 2004) or tourist destinations (Goodrich \& Goodrich, 1987) in attracting tourists. Collectively, health tourism can be defined as: "Traveling to destinations which provide facilities and services to maintain or improve health through wellness and medical tourism" (Musa et al. 2012, p. 630). Medical tourism, as suggested by Carrera and Bridges (2006), is part of health tourism. This trip aims to restore one's health through medical intervention. Although there is no universal definition of medical tourism (Crooks et al, 2010), medical tourism generally involves tourists traveling far from their home country, to at least stay overnight, for 1) paid medical care (Hall, 2011); 2) tourism events that focus on healing (Hall, 2011). Henceforth, this study uses the term medical tourism that is all activities related to the journey of a tourist who stays at least one night in a destination to maintain, improve or restoring health through medical intervention (Musa et al. 2012, p. 630).

This study intends to propose a theoretical model as shown in Figure 1 which shows a hypothetical causal relationship to measure the loyalty of Indonesian medical tourists going to Malaysia to obtain health services. Each variable in the model is chosen based on a literature review. Previous studies revealed that medical tourist loyalty is influenced by their satisfaction (Bitner, 1990; Dick \& Basu, 1994; Oliver, 1999), and satisfaction is influenced by travel motivation (Mannell \& Iso-Ahola, 1987; Dunn Ross \& Iso-Ahola, 1991; Fielding et al, 1992) while motivation is often inspired by marketing promotion programs (MPP) or word of mouth (WoM) (Subramanisan, 2018). The causal relationship that is hypothesized between satisfaction and loyalty of medical destinations is referred to as the medical tourism destination loyalty theory (Yoon \& Uysal, 2005).

Almost all motivation studies involve internal encouragement and external pull, so the hypothetical model in this study divides motivation into two variables: push and pull motivations. This model examines the structural causal relationship between MPP and WoM, push and pull, satisfaction, and destination loyalty (See Figure 1). Hypothetically, MPP and WoM drive motivation, and motivation influence tourist satisfaction with travel experiences, which in turn affects loyalty. The theoretical basis and previous research as a basis for building this model are discussed in the following sections.

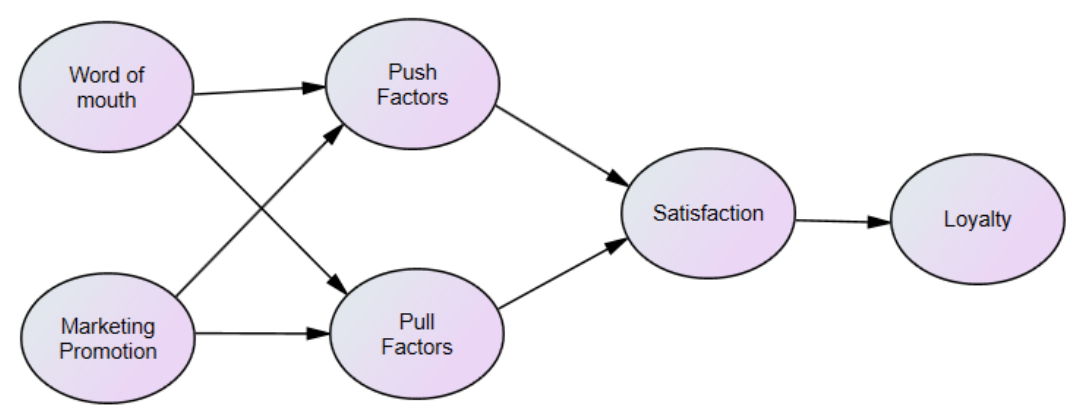

Figure 1: Theoretical Model on Loyalty

This study aims to investigate the influencer of Indonesian medical tourists, whether MPP or WoM, to get health services in Malaysia.What is the influence of MPP and WoM on the motivation (push and pull)? How motivational factors affect satisfaction and how satisfaction affect loyalty. Based on the description above, this study aims to explore the travel behaviour of health tourists from Indonesia for marketing management purposes in particular and the health sector in general and more importantly to obtain input for the health sector in Indonesia for future health service improvement. The objectives of this study are:

i. To find out which factors, between the word of mouth (WoM) or marketing promotion programs (MPP), that drive motivation (push and pull) among Indonesian medical tourists in Malaysia.

ii. To explore travel motivation (push and pull) of Indonesian medical tourists in Malaysia and its relationship with travel satisfaction.

iii. $\quad$ To investigate the satisfaction of Indonesian medical tourists in Malaysia and its relationship with loyalty.

\section{Literature Review}

\section{Travelling influencers}

The consumer behavior literature shows that every purchase decision begins with the introduction of needs (Blackwell et al, 2006), and when needs are identified, consumers usually look for information that can help make decisions to meet needs (Petty \& Cacioppo, 
1986). When advertisers can direct consumers to their marketing promotions, it gives them more opportunities to convince consumers effectively. Marangkun \& Thipjumnong (2017) found that marketing promotion programs (MPP) such as advertisements, sales promotion and public relations influence pull motivation.

Lubik et al (2012) study the market pull and technological push in new manufacturing companies (start-ups) in the emerging industries. The results of their study show that marketing opportunities that arise from public relations activities are a pull motivation for producers to participate in the industry while motivation drives operations. The MPP variables including advertising, public relations, sales promotion, and personal selling are seen as significant factors that influence push and pull motivation.

Apart from MPP, information about health services abroad can also come from daily communication. For many people, the communication they make with others is often more influential than the promotional messages they receive from the marketers. Consumers usually first gather information and opinions about a product or service from people around them before making a purchase (Attia et al, 2012). Word-of-mouth (WoM) is defined as a positive or negative statement made based on customer experience about a product or company (Naz, 2014). WoM is a communication between two people who do not have a commercial purpose (non-commercial) and without expecting benefits in the business they are talking about (Taylor et. Al, 2012).

According to the Nielsen report (2015) $83 \%$ of consumers say they fully or somewhat trust the recommendations given by family, colleagues, and friends about a product and service. This makes word of mouth recommendations as a source of consumer confidence with the highest rank. WoM plays an important role in encouraging purchases for consumers who are not exposed to the company's promotional messages, those who have never heard or thought of buying a product or service from a particular brand (Naz, 2014).

\section{Motivation}

Motivation plays an important role in the decision to undergo health services in other countries. Dann (1977) introduces push factors and pull factors to explain a person's motivation to undergo medical tourism. The study of travel motivation has long been regarded as complicated and has many facets, but generally travel motivation is examined in this push-and-pull framework (Crompton, 1979). The push factor refers to intrinsic needs and is often used to explain why people travel. The push factor is the intrinsic human desire, which includes the desire to escape, find new things, seek adventure, fulfill dreams, want to rest or relax, get health and fitness, prestige, and socialization (Uysal, M., \& Jurowski, 1993).

Pull factors refer to extrinsic needs or destination attributes. The pull factor is a specific element that drives people to realize their needs for certain travel experiences, such as natural attractions (eg beaches or mountains) or the history of a country, food, community, recreational facilities, and the image or reputation of the destination location ( Uysal \& Hagan, 1993). The main pull factor that drives health tourists to seek health services in other countries is lower costs (Gray \& Poland, 2008; Hall, 2011; Ormond, 2011). Connell (2006) adds that tourists also utilize affordable airplane tickets and favorable exchange rates to get health services. Other important factors include the availability of state-of-the-art medical facilities in the destination country and aftercare with equivalent quality (UNESCAP, 2007).

Based on the literature review discussed above, the following hypotheses can be put forward:

H1 - Marketing promotion programs (MPP) has a significant relationship with motivation (push or pull).

H2 - Word of mouth (WoM) has a significant relationship with motivation (push or pull).

\section{Medical tourists' satisfaction}

Empirical studies show that tourist satisfaction is significantly influenced by motivation (Lee, 2009). Studies to evaluate consumer satisfaction using several models including expectation/disconfirmation models (Chon, 1989; Francken \& Van Raaij, 1981; Oliver, 1980) and equity models (Oliver and Swan, 1989). According to the expectation-disconfirmation model as suggested by Oliver (1980), consumers develop expectations about a product before making a purchase. Next, they compare actual performance with previous expectations. If the actual performance is better than expectations then this leads to positive disconfirmation, which means consumers are very satisfied and will be more willing to buy the product again. If actual performance is worse than expectations, this leads to negative disconfirmation, which means consumers are dissatisfied and will likely look for alternative products or services.

Oliver and Swan (1989) are interested in equity theory. Consumer satisfaction can be seen as the relationship between the costs spent by consumers and the expected benefits. Here, price, benefits, time, and effort are the main factors in determining satisfaction (Heskett et al, 1997). Thus, it can be said that if tourists receive benefits or value that is by the time, energy, and money they spend then their visit to a destination is considered beneficial. Based on the theory and research that has been discussed, the following hypotheses can be put forward:

H3 - Motivation (push or pull) has a significant relationship with satisfaction

\section{Loyalty}

Oliver (1999) defines loyalty as: "a deeply held commitment to buy or patronize a preferred product or service consistently in the future, causing repetitive same-brand or same brand-set purchasing, despite situational influences and marketing efforts having the 
potential to cause switching behavior." (Oliver, 1999: 34). Oliver postulates that loyalty is a goal that companies must pursue to ensure success. Loyalty has a strong impact on company performance, and companies in various industries consider these two factors as important sources of competitive advantage (De Wulf et al, 2001; WG Kim \& Cha, 2002; Rust et al, 2004).

In the marketing literature, the two things most often used as indicators of consumer loyalty are repeat purchases or recommendations to others, and loyalty is an important indicator to measure the success of marketing strategies (Flavian et al, 2001). If a tourist destination can be considered a product, tourists are consumers who can make repeat purchases in the sense of visiting again or recommending a destination to other potential tourists such as friends or relatives.

According to Yoon and Uysal (2005), an understanding of tourist loyalty needs to consider motivation and satisfaction simultaneously. They show that the success of a destination is very dependent on a comprehensive analysis of travel motivation, satisfaction, and loyalty. In their study, Yoon and Uysal developed a model to examine the relationship between push and pull motivation, satisfaction, and loyalty through a structural equation modeling approach. This study found that push motivation directly affects tourist loyalty to a destination, while pull motivation influences tourist satisfaction. Based on this rationale, the following hypotheses can be put forward:

H4 - Satisfaction has a significant relationship with loyalty

\section{Research and Methodology}

This study used a survey method by distributing questionnaires to medical tourists from Indonesia $(\mathrm{N}=152)$ who visited hospitals in the three largest medical tourism destinations in Malaysia, namely Kuala Lumpur, Penang, and Malacca. The questionnaire was made in two formats namely paper format that can be directly filled in by respondents at the location and online format using Google Form that can be sent to the respondent's cell phone so it can be filled out in the most convenient opportunity for the respondent. Target respondents are patients undergoing treatment, and if not possible, they can be represented by the accompanying family. An initial questionnaire was prepared, and a trial (pretest) of the questionnaire was conducted with ten respondents and after solving several ambiguities, the questionnaires were distributed to all targeted respondent producing 152 respondents. Testing with Cronbach's alpha was carried out and all alpha values is higher than 0.7, surpassing the minimum threshold (See Table 1).

The first part of the questionnaire asked respondents to fill in demographic data of patients undergoing treatment which included: gender, age, and religion. This study will find out whether travel motivation is also influenced by travel influencers and to find out which one between the two influencers -WoM and MPP- that drive push and full factors.

The second part aims to measure each research variable based on respondents' answers. As discussed earlier, this study proposes six variables that can be categorized as follows: 1) Core endogenous variables, those are predicted by other variables in the model, and in this study are the loyalty of Indonesian medical tourists to obtain health services in Malaysia; 2) Exogenous variables is the influencers (WoM and MPP); 3) Endogenous antecedent variables are variables predicted by exogenous variables or other antecedent variables, and in this model is motivation (push and pull factors) and satisfaction.

As seen in Table 1, all variables are measured using a combination of statements and questions with responses consist of a scale from five (very strong) to one (very weak). The variable of influencers has two dimensions: WoM and MPP. WoM is measured with three statements that include: "My friends advised me to seek medical service in Malaysia"; and "I often hear positive comments about health services in Malaysia". The influence of MPP is measured with four statements among others: "I often see advertisements for Malaysian hospital" and "I often see media displaying photos of Malaysian hospitals".

To measure push variable, several statements were made including: "I went to Malaysia because I wanted to learn something new and interesting"; "I have never been to Malaysia before"; "I want to realize my dream of going abroad"; "I want to meet and mingle with Malaysians; "I want to break from my daily routine". Pull variable are measured by several statements: "The cost of health services in Malaysia is cheaper than Indonesia"; "Transportation costs to and from Malaysia are affordable"; "The currency exchange rate is quite affordable" and; "Malaysia has good health facilities"

In this study, satisfaction and loyalty are measured by following Yoon \& Uysal (2005) but with some modifications. Four questions were developed to apply the customer satisfaction theory to actual satisfaction based on experience as a medical tourist in Malaysia: (1) Is the health service in Malaysia in line with what you expect? ( $1=$ far worse than I expected, and $5=$ far better than I expected); (2) Is the time and energy you spend commensurate with what you receive? ( 1 = not very worth it, and 5 very worth it); (3) Overall, how satisfied are you with health services in Malaysia? $(1=$ very dissatisfied, and 5 = very satisfied $)$; and (4) how do you rate health services in Malaysia compared to Indonesia? $(1=$ worse, and $5=$ much better $)$.

Three indicators are used to measure tourist loyalty as the ultimate endogenous construct. Two indicators related to the desire to revisit and one indicator relating to recommendations to friends and relatives. For the first time visitors, the will to visit again are measured in the form of statements: "I will return to Malaysia for treatment if I need health services"; and questions: (1) "In the next two years, how likely are you to return to Malaysia to get health care?" ( $1=$ Not possible at all, and $5=$ Very possible); and (2) Please explain your feelings after the visit to Malaysia? $(1=$ this visit was very bad, and I will not come again and $5=$ this visit is very good so I will come again). For the multiple visitors, the visit frequency to Malaysia is used to measure loyalty. The recommendation is 
measured with the following statement: "I have told others about the superiority of hospitals in Malaysia"; "I once advised others to seek treatment in Malaysia"; "I encourage my family to seek treatment in Malaysia".

Table 1: Variable Measurements

\begin{tabular}{|c|c|c|c|}
\hline Constructs & Mean & $S D$ & Cronbach $\alpha$ \\
\hline Marketing Promotion & & & 0,965 \\
\hline I often see advertisements for Malaysian hospitals & 1,97 & 0,81 & \\
\hline I often read articles about health services in Malaysia & 2,06 & 0,82 & \\
\hline I often see media displaying photos of hospitals in Malaysia & 1,48 & 0,5 & \\
\hline I often receive information about health services in Malaysia & 1,52 & 0,5 & \\
\hline Word of mouth & & & 0,967 \\
\hline My family suggested me to seek medical service in Malaysia & 1,98 & 0,78 & \\
\hline My friends advised me to seek medical service in Malaysia & 1,88 & 0,76 & \\
\hline I often hear positive comments about health services in Malaysia & 2,96 & 0,79 & \\
\hline Push factors & & & 0,967 \\
\hline \multicolumn{4}{|l|}{ I went to Malaysia because I wanted to learn } \\
\hline something new and interesting & 1,53 & 0,5 & \\
\hline I have never been to Malaysia before & 2,01 & 0,81 & \\
\hline I want to realize my dream of going abroad & 1,5 & 0,5 & \\
\hline I want to meet and mingle with Malaysians & 1,54 & 0,49 & \\
\hline I want to break from my daily routine & 1,55 & 0,49 & \\
\hline Pull factors & & & 0,966 \\
\hline \multicolumn{4}{|l|}{ The cost of health services in Malaysia } \\
\hline is cheaper than Indonesia & 4,17 & 0,79 & \\
\hline \multicolumn{4}{|l|}{ Transportation costs to and from Malaysia } \\
\hline are affordable & 4,48 & 0,5 & \\
\hline The currency exchange rate is quite affordable & 4,52 & 0,5 & \\
\hline Malaysia has good health facilities & 4,5 & 0,49 & \\
\hline \multicolumn{4}{|l|}{ I chose Malaysia because of cultural and } \\
\hline religious similarities & 4 & 0,5 & \\
\hline I chose Malaysia because it is not far from my city & 4,04 & 0,81 & \\
\hline Satisfaction & & & 0,977 \\
\hline Is the health service in Malaysia in line with what you expect? & 4,47 & 0,5 & \\
\hline \multicolumn{4}{|l|}{ Is the time and energy you spend commensurate } \\
\hline with what you receive? & 4,44 & 0,5 & \\
\hline Overall, how satisfied are you with health services in Malaysia? & 4,52 & 0,5 & \\
\hline How do you rate health services in Malaysia compared to Indonesia? & 4,49 & 0,5 & \\
\hline Loyalty & & & 0,984 \\
\hline I will return to Malaysia for treatment & 4,03 & 0,82 & \\
\hline \multicolumn{4}{|l|}{ In the next two years, how likely are you } \\
\hline to return to Malaysia to get health care? & 0,83 & 0,82 & \\
\hline Please explain your feelings after the visit to Malaysia? & 3,93 & 0,83 & \\
\hline \multicolumn{4}{|l|}{ How many times have you visited Malaysia } \\
\hline to get health services? & 3,62 & 1,11 & \\
\hline I have told others about the superiority of hospitals in Malaysia & 2 & 0,84 & \\
\hline I advised others to seek treatment in Malaysia & 1,46 & 0,5 & \\
\hline I encourage my family to seek treatment in Malaysia & 1,96 & 0,85 & \\
\hline
\end{tabular}

\section{Data Analysis}

The questionnaires that meet the requirements were analyzed. Missing values, extreme values (outliers), and the distribution of all measured variables are examined to purify data and reduce systematic errors. Furthermore, data analysis was carried out using several statistical procedures as follows: Firstly, a multivariate test was conducted to find out whether there is a statistically significant difference in push and pull motives based on the influencers (WoM and MPP). The test aims to find out whether we have to reject or accept the null hypothesis stating that the push and pull factors are equal to all categories of the influencer. Second, a multiple linear regression is performed to find out the influence of push and pull variables on satisfaction of medical services in Malaysian hospital. Finally, a simple linear regression is performed to find out the influence of the satisfaction variable on the loyalty of Indonesia medical tourists to the Malaysian medical services. 


\section{Results \& Discussions}

Data collection was carried out from December 2019 to June 2020 in Malaysia and Indonesia. The initial stage of the collecting data process in Malaysia was hampered by the Movement Control Order (MCO) by the Malaysian federal government due to the COVID19 pandemic. The distribution of paper format questionnaires in Malaysia was canceled and then continued in Indonesia which was conducted online using snowball sampling techniques. After checking for missing values, outliers, and variables to purify data and reduce systematic errors, some 152 respondents were qualified for further analysis and their details is in Table 2.

Table 2: Descriptive Statistics

\begin{tabular}{|c|c|c|c|c|}
\hline Variables & Frequency & $\%$ & & \\
\hline \multicolumn{5}{|l|}{ Gender } \\
\hline Male & 118 & 78 & & \\
\hline Female & 34 & 22 & & \\
\hline \multicolumn{5}{|l|}{ Religion } \\
\hline Muslim & 132 & 87 & & \\
\hline Non-Muslim & 20 & 13 & & \\
\hline \multicolumn{5}{|l|}{ Age } \\
\hline $15-24$ & 175 & 55,7 & & \\
\hline $25-34$ & 68 & 21,7 & & \\
\hline $35-44$ & 39 & 12,4 & & \\
\hline $45-54$ & 27 & 8,6 & & \\
\hline Above 55 & 5 & 1,6 & & \\
\hline Variables & Min & $\operatorname{Max}$ & $M$ & $S D$ \\
\hline Loyalty (Scale 6-30) & 6 & 30 & 28 & 3,63 \\
\hline Mark. promotion (4-20) & 4 & 14 & 8 & 1,85 \\
\hline Word of Mouth (3-15) & 6 & 15 & 11 & 1,99 \\
\hline Push factors (5-25) & 13 & 25 & 19 & 2,74 \\
\hline Pull factors (4-20) & 9 & 20 & 17 & 3,12 \\
\hline Satisfaction (4-20) & 13 & 20 & 18 & 1,89 \\
\hline
\end{tabular}

The majority of Indonesian medical tourists are from Medan (45,2\%), followed by Pekanbaru (26.2\%), Padang (12,1\%), Banda Aceh $(10,1 \%)$, and Bangka (6,4\%). Males make up the majority of respondents (58.2\%). Most of the respondents are between $45-54$ years old $(40.3 \%)$, followed by those who age above 55 years old (30,1\%). About $61.9 \%$ of the respondents have at least college education. Information sources on how Indonesian medical tourists selected Malaysia as their medical tourist destination include friends and relatives $(58.2 \%)$, the marketing promotion on the Internet (16.5\%), and a combination of the two $(25,3 \%)$.

Most medical tourists travel to Malaysia with family or relatives (58.1\%). Those who travel with their spouses (28.9\%) and friends $(13.0 \%)$, respectively. The main categories of medical care services which medical tourists seek in Malaysia are consultation with specialist and drug therapist for medical treatment (55.2\%), full body checkups and wellness screenings (20.4\%), surgical procedures that include specialized and general surgery $(21.4 \%)$, and cosmetic procedures such as face lift, nose job, liposuction etc (3.1\%).

In this study, the Manova procedure is used to measure the main effect on the relationship between travel influencer variables that have nominal data consisting of WoM (coded with 1.00) and marketing promotion program (MPP, coded 2.00) and the two dependent variables (push and pull) (See Table 3). In this way, it can be seen whether the travel influencers (WoM and MPP) indeed affected the push and pull motives. There is no missing value in the data set but there is an unequal number of each category in the independent variable. The sample data indicates that some 120 respondents show a higher score for WoM, so they are grouped under the WoM category, and the remaining 32 respondents are under the MPP category. Table 3 provides the mean and standard deviation for the two different dependent variables (push and pull), which have been split by the two categories in the independent variable (WoM and MPP).

A number of statistical assumptions need to be discussed here before making calculations with ANOVA which include assumptions regarding sample size, normality, multicollinearity, and linear relationships. In terms of sample size, there are two views regarding the number of samples in ANOVA (Grande, 2015). The first view states that the minimum number of samples is 20 for each category in the independent variables. While another view states that the minimum sample size is the number of categories multiplied by the number of dependent variables. Whichever the views used, this study has a minimum sample size that exceeds both. Manova assumes normal distribution and multivariate normality in the dependent variables.

The issue of a normal distribution is resolved by conducting bootstrap in SPSS 25 that treats the non-normal data as normal by drawing 1000 subsamples randomly out of the originally collected samples. To find multivariate outliers, which indicates unusual 
combinations of two or more variables, the Mahalonobis distance is checked to find a maximum value at 13.47 which is below the critical value for two dependent variables at 13.82. So the assumption of no multivariate outlier is met.

The assumption of a linear relationship between each pair of dependent variables across each level of the independent variable is checked through scatterplots. The elliptical shapes starting from the bottom left and moving up to the top right, indicating the linear relationship, were found in most of the scatterplots.

Table 3: Push and pull variables split by WoM and MPP categories

\begin{tabular}{lllll}
\hline & Influencer & Mean & Std. Deviation & $\mathrm{N}$ \\
\hline Push & 1.00 & 8,22 & 0,85 & 120 \\
\hline & 2.00 & 6,38 & 0,71 & 32 \\
\hline Pull & Total & 7,83 & 1,11 & 152 \\
\hline & 1.00 & 26,61 & 1,19 & 120 \\
\hline & 2.00 & 24,13 & 0,83 & 32 \\
\hline
\end{tabular}

Note: 1.00 (word of mouth/WoM); 2.00 (marketing promotion program/MPP)

Multicollinearity assumption requires that the correlation between two independent variables is less than .90. In this study, the correlation between push and pull variables stands at .73. So the assumption is met, the two variables do not have issues with multicolinearity, but they are still correlated. The correlation between other variables is presented in Table 4 . The only limitation on the statistical assumption is in the box's test, the covariance matrices on the dependent variables are not equal across groups (The alpha used for this test is .001).

In the multivariate test, there was a statistically significant difference in push and pull motives based on the influencers , $F(2,149)$ $=13.74, p<.001$; Wilk's $\Lambda=0.475$, partial $\eta^{2}=.53$ (See Table 5). It means that we reject the null hypothesis stating that the push and pull factors are equal to all categories of the influencer. The partial eta squared, or the percentage of variance that explains the combination of push and pull factor by influencers is $52.5 \%$. It is a statistically significant finding with a large effect size. In the test of between-subject effect, there is a statistically significant result $(p<0.01)$ between motivation (push and pull) and the influencer (See Table 6). Referring to H1 and H2, MPP and WoM have a significant relationship with motivation (push or pull). The push and pull factors differ based on the category of influencer (WoM or MPP). The effect size of both push and pull variables is almost equal as the partial eta squared for each variable is $45.7 \%$ and $45.0 \%$ respectively. Thus $91 \%$ of travel motives are influenced by WoM or MPP, while the remaining $9 \%$ is influenced by other factors not yet known. It is clear the results of the analysis show that there is a significant difference influence between WoM and MPP in shaping the motivation (push or pull) among Indonesian medical tourists seeking health services in Malaysia.

A multiple linear regression is performed to find out the influence of the independent variables (push and pull) on the dependent variable (medical tourists' satisfaction of medical services in Malaysian hospital). The model summary shows that the relationship is statistically significant $(p<0.001)$ as $85.2 \%$ of the variance in the satisfaction is explained by push or pull variables. Individually, the independent variables also show a significant relationship with the satisfaction ( $p$ sh $\beta=0.413, p<0.05$ and pull $\beta=0.518, p<0.01$ ). So, both push and pull are significant predictors for satisfaction as $41.3 \%$ of the variance in the satisfaction is explained by push factors and $51.8 \%$ by pull factors.

Satisfaction of Indonesian medical tourists is predicted based on push and pull motives. A significant regression equation was found $(\mathrm{F}(2,149)=436.47, p<0.001)$, with an $R^{2}$ of 0.85 . Participants' predicted satisfaction is equal to $6.45+0.31$ (push) +0.35 (pull) where push and pull were measured in the scale data. The unstandardized coefficient table shows that the satisfaction level increases by 0.31 for one-unit increase in the push variable (There is a $95 \%$ chance that the actual value is between 0.12 and 0.51 ). Meanwhile, the satisfaction rises by 0.35 for one-unit increase in the pull (The actual value is between 0.18 and 0.52 ). So, when there is an increase in the push or pull, the higher the satisfaction level.

A simple linear regression is performed to find out the influence of the satisfaction variable on the loyalty of Indonesia medical tourists to the Malaysian medical services. The model summary shows that the relationship is statistically significant $(p<0.001)$ as $90.2 \%$ of the variance in the loyalty is explained by satisfaction variable. So, satisfaction is the significant predictors for loyalty. A significant regression equation was found $(\mathrm{F}(1,150)=1381, p<0.001)$, with an $R^{2}$ of 0.902 . Participants' predicted loyalty is equal to $-20.28+2.29$ (satisfaction) where satisfaction was measured in the scale data. The unstandardized coefficient table shows that the loyalty increases by almost 3.0 for one-unit increase in the satisfaction variable (There is a $95 \%$ chance that the actual value is between 0.12 and 0.51 ). Meanwhile the satisfaction rises by 0.35 for one-unit increase in the pull (The actual value is between 2.17 and 2.42). So, the more satisfaction increase, the higher the loyalty level. 
Table 4: Correlation between variables

\begin{tabular}{|c|c|c|c|c|c|c|}
\hline & promotion & WoM & push & pull & satisfaction & loyalty \\
\hline promotion & 1 & & & & & \\
\hline WoM & .103 & 1 & & & & \\
\hline push & $.232 * *$ & .563 & 1 & & & \\
\hline pull & .656 & .412 & $.727 * *$ & 1 & & \\
\hline satisfaction & .456 & .349 & .659 & .248 & 1 & \\
\hline loyalty & .543 & .421 & .420 & .549 & .417 & 1 \\
\hline
\end{tabular}

Table 5: Multivariate Tests

\begin{tabular}{llllllll}
\hline Effect & & Value & F & Hypothesis df & Error df & Sig. & $\begin{array}{l}\text { Partial Eta } \\
\text { Squared }\end{array}$ \\
\hline Influencer & Pillai's Trace & 0,525 & 82.449 & 2,000 & 149,000 & 0,000 & 0,525 \\
\hline & Wilks' Lambda & 0,475 & 82.449 & 2,000 & 149,000 & 0,000 & 0,525 \\
\hline & Hotelling's Trace & 1,107 & 82.449 & 2,000 & 149,000 & 0,000 & 0,525 \\
\hline & Roy's Largest Root & 1,107 & 82.449 & 2,000 & 149,000 & 0,000 & 0,525 \\
\hline
\end{tabular}

Table 6: Tests of Between-Subjects Effects

\begin{tabular}{llllllll}
\hline Source & & $\begin{array}{l}\text { Type III Sum } \\
\text { of Squares }\end{array}$ & df & $\begin{array}{l}\text { Mean } \\
\text { Square }\end{array}$ & F & Sig. & $\begin{array}{l}\text { Partial } \\
\text { Squared }\end{array}$ \\
\hline influencer & push & 85,686 & 1 & 85,686 & 126,174 & 0,000 & 0,457 \\
& pull & 155,796 & 1 & 155,796 & 122,938 & 0,000 & 0,450 \\
\hline
\end{tabular}

\section{Implications}

The results of the study indicate that most of the relationships between the variables proposed in this research model have strengthened previous studies. First, the need to obtain health services in Malaysia begins with information from the MPP issued by various agencies in Malaysia and also from WoM, especially from family or colleagues. This study found that $91 \%$ of travel motives are influenced by WoM or MPP, and there is a significant difference influence between WoM and MPP in shaping motivation. The results of this study reinforce previous studies that MPP such as advertisements, sales promotion and public relations influence motivation either pull or push (Marangkun \& Thipjumnong, 2017; Lubik et al, 2012). Likewise, WoM has a significant effect on motivation. As other type of consumers in general, WoM plays an important role for medical tourists who are not exposed to the promotional messages and they fully or somewhat trust more the recommendations from family, colleagues, and friends (Naz, 2014; Nielsen 2015).

Second, motivation has a significant effect on satisfaction. As WoM dan MPP shapes motivation so does the later shape satisfaction. A multiple linear regression was calculated to predict satisfaction based on push and pull variables. A significant regression equation was found $\left(\mathrm{F}(2,149)=436.47, p<0.001\right.$, with an $\mathrm{R}^{2}$ of 0.85 . Participants' predicted satisfaction is equal to $6.45+0.31$ (push) + 0.35 (pull), where push and pull were measured in scale data. Participants' satisfaction increased 0.31 for each unit of push rise and 0.35 for each unit of pull rise. Both variables of push and pull were significant predictors of satisfaction.

The results of this regression test indicate that the two elements that makeup motivation, push and pull, have almost the same effect on satisfaction. The model summary indicates $85.4 \%$ of the variance in the satisfaction is explained by push or pull variables. Individually, push and pull contribute $41.3 \%$ and $51.8 \%$ respectively of the variance in the satisfaction. This research justifies most of the attributes of the push and pull variables including extrinsic (lower medical cost, affordable airplane tickets and favourable exchange rates) (Connell, 2006) and the intrinsic human desire as discussed by Uysal and Jurowski (1993).

Third, a simple linear regression was calculated to predict loyalty based on satisfaction. A significant regression equation was found $(\mathrm{F}(1,150)=1380.94, p<0.001)$, with an $\mathrm{R}^{2}$ of .902 . Participants' predicted loyalty is equal to $-20.28+2.29$ (satisfaction) where satisfaction is measured in interval data. Participants' loyalty increased 2.29 for each unit of satisfaction rise. So, this study finds $90.2 \%$ of the variance in the loyalty is explained by satisfaction variable alone. So, satisfaction is the significant dominant predictors for loyalty supporting previous study for example Yoon and Uysal (2005). 
This study has limitations in terms of the relatively small number of samples even though it meets the minimum requirements for statistical calculations. Also, a handful of questionnaires were not filled in directly by the patient because of various considerations but were represented or filled out by a companion, for example: the patient's wife or child. However, this is not expected to cause bias due to the emotional closeness between the patient and the person who filled out the questionnaire. In the end, this research makes an important contribution to the health and tourism industry, especially to improve the performance of this sector. However, further research is needed to determine which medical tourist characteristics are more influenced by push or pull motivation. The results of this study indicate that very service-oriented hospital marketing is the same as the marketing of goods in the manufacturing industry or other industries because it uses the same marketing principles.

\section{Conclusion}

The findings show that there is a statistically significant difference in push and pull motives based on the influencers. So, the push and pull differ based on the category of influencer (WoM or MPP). The effect size of both push and pull is almost equal as the partial eta squared for each variable is $45.7 \%$ and $45.0 \%$ respectively. Thus $91 \%$ of travel motives are influenced by WoM or MPP, while the remaining $9 \%$ is influenced by other factors not yet known. It is clear the results of the analysis show that there is a difference in influence between WoM and MPP in shaping the motivation (push or pull) among Indonesian medical tourists seeking health services in Malaysia. The relationship between motive (push or pull) and satisfaction is also statistically significant as $85.2 \%$ of the variance in the satisfaction is explained by push or pull and $41.3 \%$ of the variance in the satisfaction is explained by push and $51.8 \%$ by pull factors. Finally, satisfaction is a significant predictor for loyalty as $90.2 \%$ of the variance in the loyalty is explained by satisfaction variable.

\section{Reference}

Attia, A. M., Aziz, N., \& Friedman, B. A. (2012). The impact of social networks on behavioral change: a conceptual framework. World Review of Business Research, 2 (3), 91-108.

Briandana, R., Doktoralina, C., M., \& Sukmajati, D. (2018). (PDF) Promotion Analysis of Marine Tourism in Indonesia: A Case Study. European Research Studies Journal, 21(1), 602-613.

Blackwell, D. R., Miniard, W. P., \& Engel, F. J. (2006). Consumer behaviour.South-western. Maso

Bitner, M.J. (1990). Evaluating service encounters; The effects of physical surroundings and employee responses. Journal of Marketing, Vol. 54 (April), pp. 69-82.

Carrera P, Bridges J (2006). Health and medical tourism: What they mean and imply for health care systems. Health and Ageing. Vol. 15. The Geneva Association.

Chon, K. (1989). Understanding recreational travelers' motivation, attitude and satisfaction. The Tourist Review, 44 (1), 3-7

Connell, J. (2006). Medical tourism: Sea, sun, sand and ... surgery. Tourism Management, 27(6), 1093-1100. https://doi.org/10.1016/J.TOURMAN.2005.11.005

Crompton, J. L. (1979). Motivations for pleasure vacation. Annals of tourism research, 6 (4), 408 - 424.

Dann, G. M. S. (1977). Anomie, ego-enhancement and tourism. Annals of Tourism Research, 4(4), 184-194. ttps://doi.org/10.1016/0160-7383(77)90037-8

De Wulf, K., Odekerken-Schröder, G., \& Iacobucci, D. (2001). Investments in Consumer Relationships: A Cross-Country and Cross-Industry Exploration. Journal of Marketing, 65(4), 33-50. https://doi.org/10.1509/jmkg.65.4.33.18386

Dick, A \& Basu, K (1994) Customer loyalty: Toward an integrate conceptual framework. Journal of the Academy of Marketing Science, 22 (2). pp. 99-113.

Flavian, C., Martinez, E., \& Polo, Y. (2001). Loyalty to grocery storesin the Spanish market of the 1990s. Journal of Retailing and Consumer Services, 8 (2), 85-93

Foster, B. D., \& Cadogan, J. W. (2000). Relationship selling and customer loyalty: an empirical investigation. Marketing Intelligence \& Planning, 18(4), 185-199. https://doi.org/10.1108/02634500010333316

Fielding, K., P. L. Pearce, and K. Hughes (1992) Climbing Ayers rock: relating visitor motivation, time, perception and enjoyment. Journal of Tourism Studies 3(2):49 - 57.

Francken, D. A., \& van Raaij, W. F. (1981). Satisfaction with leisuretime activities. Journal of Leisure Research, 13 (4), $337-352$

Goodrich, J.N., Goodrich, G.E. (1987). Health-care tourism - an exploratory study. Tourism Management, 8(3): 217-222.

Grande, T (2015). Conducting a MANOVA in SPSS with Assumption Testing. YouTube. https://www.youtube.com/watch? $=$ rCgeWeXRtDs\&t=181s

Gray, H. H., \& Poland, S. C. (2008). Medical Tourism: Crossing Borders to Access Health Care. Kennedy Institute of Ethics Journal, 18(2), 193-201. https://doi.org/10.1353/ken.0.0006

Hall, C. M. (2011). Health and medical tourism: a kill or cure for global public health? Tourism Review, 66(1/2), 4-15. https://doi.org/10.1108/16605371111127198

Hair, J. F., Anderson, R. E., Tatham, R. L., \& Black, W. C. (1998). Multivariate data analysis(5th edn).). New Jersey: Prentice Hall.

Handayani, I. (2019). 60\% Pasien Asing di Malaysia Berasal Dari Indonesia. Retrieved December 11, 2019, from Investor Daily website: https://www.beritasatu.com/kesehatan/538106/60-pasien-asing-di-malaysia-berasal-dari-indonesia 
Heskett, J. L., Sasser, W. E., \& Schlesinger, L. A. (1997). The service profit chain. New York, NY: The Free Press.

Herrick, D. (2017). News - Mexico Is Attracting U.S. Medical Tourists | Heartland Institute. Retrieved December 11, 2019, from The Heartland Institute website: https://www.heartland.org/news-opinion/news/mexico-is-attracting-us-medicaltourists?source=policybot

Horowitz, M. D., \& Rosensweig, J. A. (2007). Medical tourism--health care in the global economy. Physician Executive, 33(6), 24-26, 28-30. Retrieved from http://www.ncbi.nlm.nih.gov/pubmed/18092615

Hyun, S. S. (2010). Predictors of Relationship Quality and Loyalty in the Chain Restaurant Industry. Cornell Hospitality Quarterly, 51(2), 251-267. https://doi.org/10.1177/1938965510363264

IUOTO (1973), Health Tourism, United Nations, Geneva.

Jais, A. S. (2017). The healthcare tourism: feasibility and future outlook for Malaysia. Retrieved from https://www.academia.edu/31672875/the_healthcare_tourism_feasibility_and_future_outlook_for_malaysia

Johns, N., \& Pine, R. (2002). Consumer behaviour in the food service industry: a review. International Journal of Hospitality Management, 21(2), 119-134. https://doi.org/10.1016/S0278-4319(02)00008-7

Kim, W. G., \& Cha, Y. (2002). Antecedents and consequences of relationship quality in hotel industry. International Journal of Hospitality Management, 21(4), 321-338. https://doi.org/10.1016/S0278-4319(02)00011-7

Kim, Y. M., Putjuk, F., Basuki, E., \& Kols, A. (2003). Increasing patient participation in reproductive health consultations: an evaluation of \&quot;Smart Patient\&quot; coaching in Indonesia. Patient Education and Counseling, 50(2), 113-122. https://doi.org/10.1016/s0738-3991(02)00193-3

Klijs, J., Ormond, M., Mainil, T., Peerlings, J., \& Heijman, W. (2016). A state-level analysis of the economic impacts of medical tourism in Malaysia. Asian-Pacific Economic Literature, 30(1), 3-29. https://doi.org/10.1111/apel.12132

Lee, T H. (2009). A structural model to examine how destination image, attitude, and motivation affect the future behaviour of tourists. Leisure Sciences, 31(3): 215-236.

Lubik, S., Lim, S., Platts, K., \& Minshall, T. (2012). Market-pull and technology-push in manufacturing start-ups in emerging industries. Journal of Manufacturing Technology Management, 24(1), 10-27.

Mannel, R. \& Iso-Ahola, S (1987). Psychological nature of leisure and tourism experience. Annals of Tourism Research, 14 (3). 314-29.

Marangkun, W \& Thipjumnong, A (2017). The Relationship Between Marketing Promotion of Historical Tourism and Tourist Motivation of Domestic Tourists: Case Study of KohYoh, Songkhla Province, Thailand. Journal of Tourism and Hospitality Management, 5(1), 25-37 doi: 10.17265/2328-2169/2017.02.002

Martovič, M. (2017). Medical tourism in global market. Retrieved from https://www.academia.edu/35775591/medical_tourism_in_global_market

Musa, G., Thirumoorthi, T., \& Doshi, D. (2012). Travel behaviour among inbound medical tourists in Kuala Lumpur. Current Issues in Tourism, 15(6), 525-543. https://doi.org/10.1080/13683500.2011.626847

Nathan, L. (2018). Medical tourism expected to reach RM2.8b in revenue by 2020. Retrieved December 11, 2019, from The Malaysia Reserve website: https://themalaysianreserve.com/2018/09/04/medical-tourism-expected-to-reach-rm2-8b-inrevenue-by-2020/

Naudé, P., \& Buttle, F. (2000). Assessing Relationship Quality. Industrial Marketing Management, 29(4), 351-361. https://doi.org/10.1016/S0019-8501(00)00112-7

Naz, F (2014). Word of Mouth and Its Impact on Marketing. International Journal of Scientific and Research Publications, 4 (1), 1 $-4$

Nielsen (2015). Digital formats are among the most trusted advertising sources despite slow growth. Retrieved from

https://www.nielsen.com/us/en/insights/article/2015/digital-formats-are-among-the-most-trusted-advertising-sources-despite-slowgrowth/

Oliver, R. (1999). Satisfaction: A Behavioral Perspective on the Consumer - Richard L. Oliver - Google Books. Retrieved from https://books.google.co.id/books/about/Satisfaction.html?id=IJ5846z99tIC\&redir_esc=

Oliver, R. L. (1999). Whence consumer loyalty? Journal of Marketing, 63, 33-44

Ormond, M. (2011). Medical tourism, medical exile: Responding to the cross-border pursuit of healthcare in Malaysia. In C. Minca \& T. Oakes (Ed.), Real tourism: Representation, practice and the 'material' in contemporary travel (pp. 143-161). London: Routledge.

Oliver, R. L. (1980). A cognitive model of the antecedents and consequences of satisfaction decisions. Journal of Marketing Research, 17 (2), 46-49

Oliver, R. L., \& Swan, J. E. (1989). Consumer perceptions of interpersonal equity and satisfaction in transactions: A field surveyapproach. Journal of Marketing, 53, 21-35.

Petty, R E.; Cacioppo, J T. (1986). Communication and persuasion: central and peripheral routes to attitude change. Berlin, Germany: Springer-Verlag. p. 4. ISBN 978-0387963440.

Roberts, K., Varki, S., \& Brodie, R. (2003). Measuring the quality of relationships in consumer services: an empirical study. European Journal of Marketing, 37(1/2), 169-196. https://doi.org/10.1108/03090560310454037 
Román, S. (2003). The Impact of Ethical Sales Behaviour on Customer Satisfaction, Trust and Loyalty to the Company: An Empirical Study in the Financial Services Industry. Journal of Marketing Management, 19(9), 915-939. https://doi.org/10.1362/026725703770558268

Rust, R. T., Lemon, K. N., \& Zeithaml, V. A. (2004). Return on Marketing: Using Customer Equity to Focus Marketing Strategy. Journal of Marketing, 68(1), 109-127. https://doi.org/10.1509/jmkg.68.1.109.24030

Shamdasani, P. N., \& Balakrishnan, A. A. (2000). Determinants of Relationship Quality and Loyalty in Personalized Services. Asia Pacific Journal of Management, 17(3), 399-422. https://doi.org/10.1023/A:1015834214570

Singh, J., \& Sirdeshmukh, D. (2000). Agency and Trust Mechanisms in Consumer Satisfaction and Loyalty Judgments. Journal of the Academy of Marketing Science, 28(1), 150-167. https://doi.org/10.1177/0092070300281014

Soriano, R. D. (2002). Customers' expectations factors in restaurants. International Journal of Quality \& Reliability Management, 19(8/9), 1055-1067. https://doi.org/10.1108/02656710210438122

Storbacka, K., Strandvik, T., \& Grönroos, C. (1994). Managing Customer Relationships for Profit: The Dynamics of Relationship Quality. International Journal of Service Industry Management, 5(5), 21-38. https://doi.org/10.1108/09564239410074358

Sun, L.-H. (1995). Consumer Involvement in Restaurant Selection. Journal of Nutrition in Recipe \& Menu Development, 1(2), 4558. https://doi.org/10.1300/J071v01n02_04

Subramanian, K, R (2018). Social media and the word of mouth publicity. International Research Journal of Advanced Engineering and Science, 3 (2), 95-100.

Taylor, D. G., Strutton, D., \& Thompson, K. (2012). Self-Enhancement as a Motivation for Sharing Online Advertising. Journal of interactive marketing, 12(2), 28.

Thomas, J. (2019). Malaysia's medical tourism on a high | The ASEAN Post. Retrieved December 11, 2019, from The Asean Post website: https://theaseanpost.com/article/malaysias-medical-tourism-high

UNESCAP. (2007). Patients without borders: An overview of the medical travel industry in Asia, its challenges and opportunities. Yoon, Y. \& Uysal, M. (2005) An Examination of the Effects of Motivation and Satisfaction on Destination Loyalty: A Structural Model.Tourism Management, 26, 45-56. https://doi.org/10.1016/j.tourman.2003.08.016

Uysal, M., \& Hagan, L. A. R. (1993). Motivation of pleasure travel and tourism. In M. O. M. Khan \& \& T. Var (Eds.), Encyclopaedia of hospitality and tourism (pp. 789-810). New York: Van Nostrand Reinhold.

Uysal, M., \& Jurowski, C. (1993). An empirical testing of the push and pull factors of tourist motivations. Annals of Tourism Research, 21(4), 844-846.

Publisher's Note: SSBFNET stays neutral with regard to jurisdictional claims in published maps and institutional affiliations.

\section{(c) (1)}

(C) 2021 by the authors. Licensee SSBFNET, Istanbul, Turkey. This article is an open access article distributed under the terms and conditions of the Creative Commons Attribution (CC BY) license (http://creativecommons.org/licenses/by/4.0/).

International Journal of Research in Business and Social Science (2147-4478) by SSBFNET is licensed under a Creative Commons Attribution 4.0 International License. 